CARADDE: Jurnal Pengabdian Kepada Masyarakat
$\begin{gathered}\text { https://journal.ilininstitute.com/index.php/caradde } \\ \text { Volume 2 | Nomor 2 | Februari | 2020 } \\ \text { e-ISSN: } 2621-7910 \text { dan p-ISSN: 2621-7961 }\end{gathered}$
DOI: https://doi.org/10.31960/caradde.v2i2.396

\title{
Pendampingan Manajemen Usaha dan Permodalan pada UKM Batu Bata
}

\section{Hendra Hadiwijaya ${ }^{1}$, Febrianty $^{2}$, Darmawi $^{3}$}

Keywords :

PKM batu bata, manajemen bisnis, modal,

Banyuasin

\section{Corespondensi Author}

Ilmu Manajemen, Politeknik

Palcomtech, Jl. Basuki Rahmat No. 5B

Palembang, Sumatera Selatan

Email: hendra_hadi@palcomtech.ac.id

\section{History Article}

Received: 05-Januari-2020;

Reviewed: 12-Januari-2020;

Accepted: 18-Februari-2020;

Avalaible Online: 18-Februari-2020;

Published: 20-Februari-2020

\begin{abstract}
Abstrak. Tujuan kegiatan adalah untuk meningkatkan manajemen bisnis, pengetahuan tentang strategi pemasaran produk dan modal bisnis/kredit bank. Tahapan implementasi PKM meliputi: Tahap Pembuatan Teknologi Tepat Guna ecommerce web, fase pelatihan meliputi: Pelatihan Manajemen Bisnis (Pelatihan tentang persiapan dan penyajian laporan keuangan dan pelatihan strategi pemasaran), pelatihan penggunaan e-commerce, permodalan pelatihan dan simulasi manajemen membuat proposal untuk mengajukan kredit bank, dan tahap Evaluasi PKM. Hasil yang dicapai: telah memberikan keterampilan keterampilan kepada Bisnis Batu Bata Daslan untuk mencatat transaksi keuangan dan menyajikan laporan bisnis dengan rapi, benar dan berkesinambungan, meningkatkan pergantian bisnis lebih dari sebelumnya menjadi $75 \%$. Peningkatan pengetahuan tentang modal usaha/kredit bank yaitu: pemahaman dalam membuat proposal kredit bank sebesar $70 \%$.
\end{abstract}

\begin{abstract}
The aim of the activity is to improve business management, knowledge of product marketing strategies and business capital / bank credit. The stages of PKM implementation include: The Making Phase of Appropriate Technology e-commerce web, the training phase includes: Business Management Training (Training on preparation and presentation of financial statements and marketing strategy training), e-commerce use training, capital training and management simulation making proposals for apply for bank credit, and the PKM Evaluation stage. Results achieved: have given Daslan Batu Business skills to record financial transactions and present business reports neatly, correctly and continuously, increasing business turnover more than before to $75 \%$. Increased knowledge about venture capital / bank credit, namely: understanding in making bank credit proposals by $70 \%$.
\end{abstract}

\section{PENDAHULUAN}

Usaha Batu Bata Daslan merupakan salah satu bangsal batu bata yang berada di Jl. Camat Km.16 Desa Pasir Putih Ujung
Kecamatan Talang Kelapa Kabupaten Banyuasin dan menjadi mitra pengabdian masyarakat Program Kemitraan Masyarakat (PKM). Usaha Batu Bata Daslan yang dimiliki oleh Bapak Daslan ini berdiri sejak 
tahun 2005, memiliki 13 pekerja tetap. Hasil produksi dipasarkan disekitar wilayah dan juga sampai ke Kota Palembang, Kota Prabumulih, dan Kabupaten Muba. Omset usaha yang dicapai sebulannya rata-rata hanya $60 \%$ dan menurun saat bulan puasa dan lebaran dikarena pada saat tersebut masyarakat tidak melakukan permintaan batu bata (masyarakat sedikit yang melakukan pembangunan rumah).

Walaupun usaha mitra telah berdiri sejak lama akan tetapi manajemen usaha masih bersifat kekeluargaan. Berdasarkan hasil wawancara dengan Pak Daslan didapatkan informasi bahwa usahanya hanya menggunakan pencatatan pesanan dan transaksi keuangan di kertas-kertasnya saja, pemasaran hanya dilakukan melalui brosur/flyer dan "mulut ke mulut" serta tidak memiliki pengetahuan cara bagaimana mendapat akses permodalan usaha/bank. (wawancara tanggal 21 Juli 2108).

Kurangnya pengetahuan manajemen usaha dan strategi pemasaran produk batu bata menyebabkan usaha mitra sulit berkembang. (Ebert \& Griffin, 2007), manajemen sebagai sebuah proses perencanaan, pengorganisasian, pengkoordinasian, dan pengontrol sumber daya untuk mencapai sasaran secara efektif dan efisien. Jadi, agar usaha dapat berjalan dengan maksimal sesuai dengan rencana yang telah ditentukan maka perlu diterapkan manajemen keuangan, manajemen SDM, manajemen operasional, manajemen pemasaran. Apalagi jika dikaitkan dengan pemasaran usaha batu bata Daslan yang masih konvensional, seharusnya telah memanfaatkan teknologi untuk menangkap permintaan batu batu yang semakin meningkat. Seperti diketahui, manajemen pemasaran adalah kegiatan menganalisis, merencanakan, melaksanakan, dan mengendalikan program-program yang disusun dalam pembentukan, pembangunan, dan pemeliharaan keuntungan dari pertukaran/transaksi melalui sasaran pasar dengan harapan untuk mencapai tujuan perusahaan dalam jangka panjang (Assauri, 2013). Oleh karena itu, bagi Usaha Kecil dan Menengah (UKM), memanfaatkan strategi pemasaran berbasis teknologi menjadi penting dan merupakan tuntutan untuk meningkatkan daya saing.
Disamping itu, maju mundurnya usaha juga tergantung pada seberapa jitu strategi pemasaran. Salah satu strategi pemesaran adalah dengan penerapan media sosial dimana untuk pemasaran tidak hanya membantu memasarkan produk dan layanan, mengurangi biaya promosi, melengkapi merek, dan melakukan komunikasi timbal balik dengan pelanggan dan pemasok tetapi juga memiliki peran untuk membantu mengidentifikasi pelanggan, berbagi informasi untuk mengetahui objek yang disukai pelanggan, keberadaan pelanggan berdasarkan lokasi dan pola interaksi, reputasi perusahaan berkenaan dengan opini pelanggan dan kelompok pelanggan yang telah mapan (Febrianty et al., 2019). Hasil penelitian (Wibowo et al., 2015) menghasilkan bahwa analisis efektifitas strategi pemasaran menunjukkan adanya peningkatan total penjualan dari tahun ke tahun dan dijadikan dasar efektifitas strategi pemasaran dalam persaingan antar perusahaan batik. Menurut (Purwanto, 2008) analisis strategi meliputi "segitiga strategi", yaitu: Pelanggan, Pesaing dan Perusahaan. Kebanyakan usaha melakukan kegiatan produksi dan operasinya hanya sampai berkonsentrasi pada pembuatan produk saja, termasuk perusahaan berskala kecil hingga menengah. Perusahaan seharusnya juga memperhatikan strategi usaha guna mempertahankan mengembangkan usaha yang sudah ada, agar tetap dapat bersaing. Beberapa strategi pemasaran yang umumnya digunakan adalah (SWOT) dan Business Model Canvas (BMC). Menurut (Ching, Hong \& Fauvel, 2013) BMC memberikan wawasan bagi pengusaha dan pebisnis mengenai variasi yang berbeda yang lebih sesuai untuk bisnis mereka. Selain itu dalam menggunakan BMC pebisnis dapat mengidentifikasi biaya yang tidak efektif dan berlebihan dalam menciptakan value bagi konsumen.

Oleh karena itu, Program Kemitraan Masyarakat (PKM) ini memberikan solusi berupa perbaikan manajemen usaha dan permodalan pada "Usaha Batu Bata Daslan". Berdasarkan hasil kunjungan lapangan, wawancara, dan pengamatan terhadap Mitra, dapat diidentifikasi beberapa permasalahan prioritas yang dihadapi mitra pada Mitra Usaha Batu Bata Daslan Desa Pasir Putih 
Hendra Hadiwijaya, Febrianty, Darmawi. Pendampingan Manajemen Usaha

Kecamatan Talang Kelapa Kabupaten Banyuasin, yakni: (1) Usaha dijalankan masih bersifat kekeluargaan dan kurangnya pengetahuan mengenai manajemen usaha yang professional; (2) Kurangnya pengetahuan mengenai strategi pemasaran produk karena masih bersifat menunggu pembeli dan menyetok batu bata; (3) Modal sangat terbatas dan kurangnya akses informasi atas dana pinjaman modal/kredit bank.

Berdasarkan permasalahan prioritas yang harus ditangani maka beberapa solusi yang ditawarkan kepada mitra adalah sebagai berikut: (a) Pendampingan untuk meningkatkan manajemen usaha melalui: Pelatihan pembuatan dan penyajian laporan keuangan dan Pelatihan strategi pemasaran. (b) Meningkatkan pengetahuan mengenai strategi pemasaran produk melalui e-commerce yang akan dihasilkan dan dan pelatihan penggunaan. Disamping itu, akan dihasilkan juga aplikasi perhitungan stock batu bata yang akan memudahkan untuk mengetahui jumlah stock batu bata dan mencatat transaksi penjualan/pemesanan. (c) Meningkatkan pengetahuan mengenai permodalan usaha/kredit bank melalui pelatihan manajemen permodalan bagi usaha mikro dan simulasi pembuatan proposal pengajuan kredit bank.

Target Luaran dari kegiatan pengabdian ini adalah: a). Pendampingan manajemen usaha, Indikator dari keberhasilan kegiatan PKM berupa peningkatan manajemen usaha pada mitra yakni: telah diterapkannya penyajian laporan keuangan usaha yang rapi dan baik secara kontinu, serta penerapan strategi pemasaran pada usaha. Terdapat kenaikan omset usaha sebesar 30\% dari kondisi sebelumnya. b). Meningkatkan pengetahuan mengenai strategi pemasaran produk. Indikator dari keberhasilan kegiatan PKM berupa peningkatan pengetahuan mengenai strategi pemasaran produk pada mitra yakni: diterapkannya secara $100 \%$ e-commerce dan aplikasi perhitungan stock batu bata secara kontinu. c. Meningkatkan pengetahuan mengenai permodalan usaha/kredit bank, Indikator dari keberhasilan peningkatan pengetahuan mengenai permodalan usaha/kredit bank pada mitra yakni: pemahaman dalam pembuatan proposal kredit bank.

\section{METODE}

Tahapan dalam pelaksanaan PKM ini adalah sebagai berikut: Tahap pelatihan yang meliputi: Pelatihan Manajemen Usaha (Pelatihan pembuatan dan penyajian laporan keuangan dan Pelatihan strategi pemasaran) dan pelatihan manajemen permodalan bagi usaha mikro dan simulasi pembuatan proposal pengajuan kredit bank, dan tahap Evaluasi PKM.

Mekanisme Pelaksanaan. Rencana kegiatan yang menunjukan langkah-langkah solusi atas persoalan pada kedua aspek yaitu: (1). Tahap Analisis Situasi dan Kondisi Mitra, Pada tahap ini tim pelaksana melalukan survey, pengumpulan data, dan identifikasi masalah mitra, serta melakukan Focus Group Discussion (FGD) dengan mitra untuk jadwal pelaksanaan kegiatan PKM; (2) Tahap Pelatihan, Pada tahap ini Tim pelaksana akan memulai kegiatan pelatihan sesuai dengan jadwal yang sudah ditentukan dan disepakati bersama dengan mitra. Tahap pelatihan yang meliputi: a). Pelatihan Manajemen Usaha (Pelatihan pembuatan dan penyajian laporan keuangan dan Pelatihan strategi pemasaran). Pelatihan ini dipandu dengan modul dan dipandu oleh Dr. Febrianty, S.E., M.Si. (anggota PKM), pemilik usaha diajarkan pembuatan dan penyajian laporan keuangan yang baik dan pembuatan strategi pemasaran dengan menggunakan BMC. BMC ini adalah konsep model yang dikembangkan oleh Alexander Osterwalder dan Yves Pigneur, yang memetakan ke dalam 9 elemen kotak yakni: Customer Segment, Value Proposition, Channel, Customer Relationship, Revenue Stream, Key Resourcess, Key Activities, Key Partnership, dan Cost Structure (kompasiana.com). Menurut Osterwalder and Pigneur (2010), BMC adalah alat yang digunakan untuk mendeskripsikan, menganalisa,dan merancang model bisnis. Business Model Canvas juga bisa diartikan sebagai bahasa yang sama untuk memvisualisasikan, menilai, dan mengubah model bisnis. b). Pelatihan manajemen permodalan bagi usaha mikro dan simulasi pembuatan proposal pengajuan kredit bank. Pelatihan ini dipandu dengan modul dan dipandu oleh Hendra Hadiwijaya, S.E., M.Si. (Ketua PKM), dimana pemilik 
Caradde: Jurnal Pengabdian Kepada Masyarakat

Vol 2 No 2, Februari 2020

usaha dilatih bagaimana membuat proposal kredit dan proses pengajuannya ke bank serta syarat-syarat apa saja yang harus dipenuhi sebagai kelengkapan administrasinya. Sedangkan untuk pelatihan teknis penggunaan e-commerce oleh Dr. Darmawi, M.T. (anggota PKM); (3) Tahap Evaluasi PKM. Pada tahap ini pelaksanaan kegiatan evaluasi oleh tim sendiri dan melihat apa saja kendala dan masalah yang muncul di lapangan. Kemudian dilakukan evaluasi apabila memang muncul kendala dan masalah untuk selanjutnya dicarikan solusi agar kegiatan tetap berlangsung dengan baik sesuai yang diharapkan.

\section{HASIL DAN PEMBAHASAN}

Sosialisasi ke mitra dilaksanakan pada tanggal 5 Maret 2019 yang ditujukan untuk menjelaskan bahwa kegiatan PKM ini didanai oleh RistekDikti dan bagaimana mekanismenya. Dalam kegiatan sosialisasi juga disusun jadwal pelaksanaan setiap tahapan PKM ke mitra.

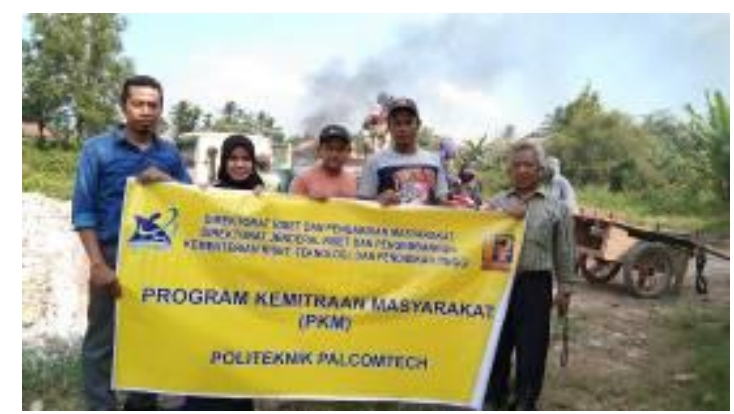

Gambar 1. Sosialisasi ke Mitra mengenai Kegiatan PKM

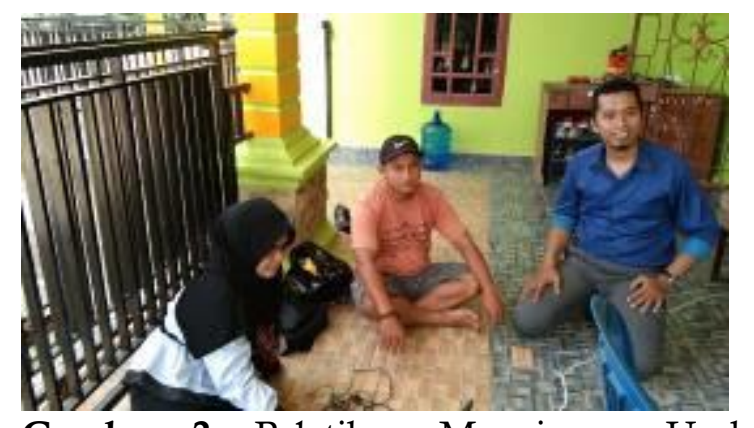

Gambar 2. Pelatihan Manajemen Usaha (Pembuatan dan penyajian laporan keuangan)

Pelatihan pembuatan dan penyajian laporan keuangan dilaksanakan tanggal 5 Juli 2019 yang dipandu oleh anggota pengabdi Dr.
Febrianty, S.E., M.Si. Mitra diberikan pengetahuan mengenai pencatatan transaksi keuangan ke dalam jurnal dengan menempatkan mana akun yang di Debet maupun yang di Kredit. Mitra juga diberikan pengetahuan dan keterampilan menyajikan laporan keuangan laba/rugi usaha. Hal ini telah memberikan perubahan kepada pemilik usaha dengan mulainya Pak Daslan menggunakan Buku Khusus untuk mencatat seluruh transaksi keuangan usaha. Selanjutnya pendampingan tetap dilakukan untuk memonitoring agar keterampilan akuntansi tersebut tetap dilakukan dalam rangka perbaikan manajemen "Usaha Batu Bata Daslan". Seperti Hal pengabdian yang penahnah dilakukan oleh (Zubaidah, 2018) dalam pendampingan dan pelatihan dalam penyusunan perencanaan keuangan, analisis BEP (Break Event Point), pengelolaan keuangan dan pembukuan dengan pendekatan yang digunakan adalah dengan pendampingan dan tutorial. Sebuah sistem baru umumnya akan dianggap rumit, kompleks, canggih, dan lain sebagainya sehingga terdapat unsur penghindaran/penolakan oleh penggunanya (sistem tidak akan sering digunakan) padahal tolak ukur penerimaan sebuah sistem dilihat dari penggunaannya. Suatu sistem sering digunakan biasanya ditunjukkan dengan sistem tersebut lebih dikenal, lebih mudah digunakan, dan atau dioperasikan (Divianto \& Febrianty, 2017). Oleh karena itu, pencatatan transaksi keuangan dan penyajian laporan keuangan menggunakan SAK ETAP.

Pelatihan penggunaan e-commerce dilaksanakan tanggal 15 Juli 2019. Pemilik usaha yakni Pak Daslan telah dapat megelola e-commerce usahanya mulai dari mempromosikan berbagai jenis produk batu batanya, merespon pesanan konsumen, dan meng-update informasi (informasi pelayanan, menambahkan foto-foto di galeri, informasi ketersediaan stock batu bata), membuat FAQ, dan lain sebagainya. Setelah diberikan penjelasan, dilakukan pendampingan kepada mitra jika terdapat kendala dalam pengelolaan web usaha tersebut. Berikut ini adalah tampilan halaman utama e-commerce "Usaha Batu Bata Daslan". 


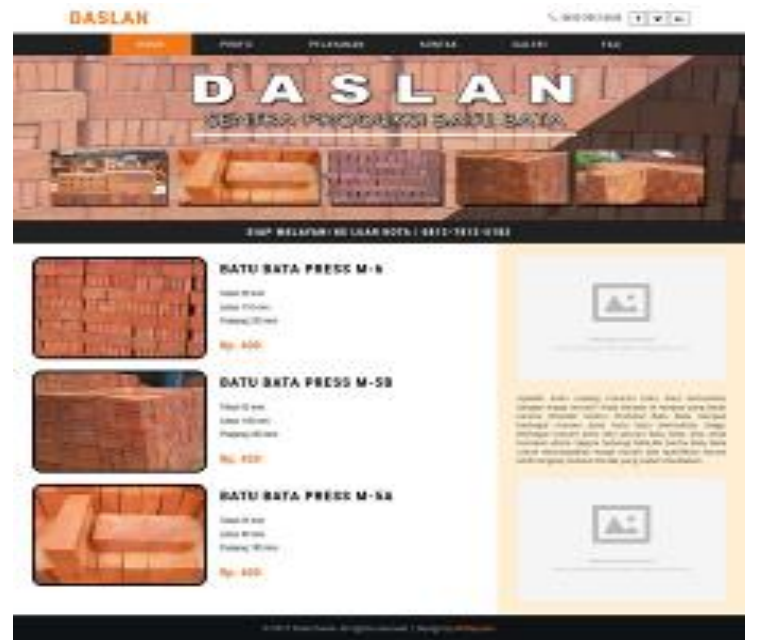

Gambar 3. Tampilan Website e-Commerce Daslan (Sentra Produksi Batu Bata)

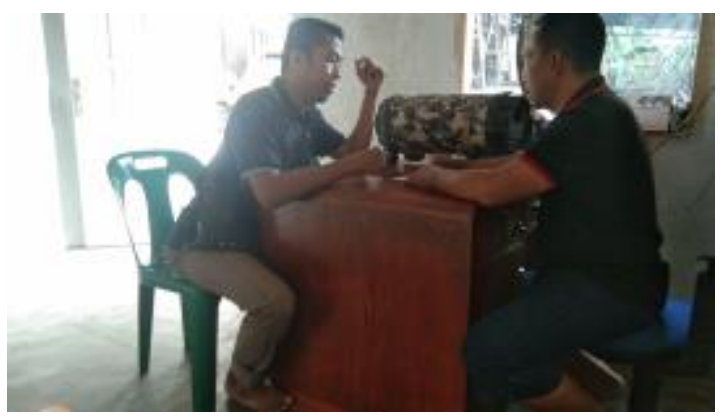

Gambar 4. Pelatihan Manajemen Usaha (Pelatihan strategi pemasaran $\mathrm{BMC})$

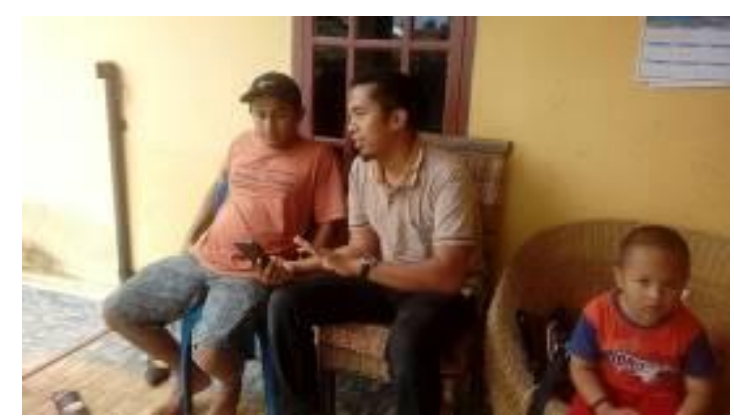

Gambar 5. Pengenalan Seputar website ecommerce

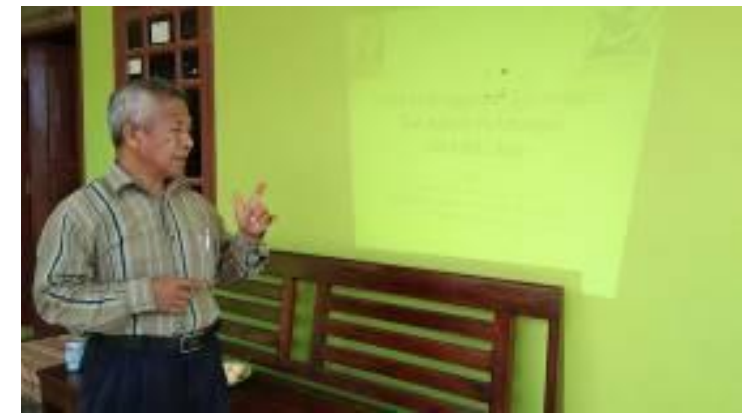

Gambar 6. Pelatihan Teknis Penggunaan e-Commerce oleh Dr. Darmawi, M.T. (anggota PKM)
Dalam pelatihan manajemen usaha, mitra juga diberikan keterampilan untuk mebuat strategi pemasaran dengan menggunakan model BMC. Pelatihan tersebut dilaksanakan tanggal Tanggal 18 Juli 2019. Mitra telah dapat menentukan secara sederhana 9 komponen dalam BMC. Berikut ini adalah alat peraga yang digunakan untuk menjelaskan dan mensimulasikan Model BMC dalam melakukan strategi pemasaran.

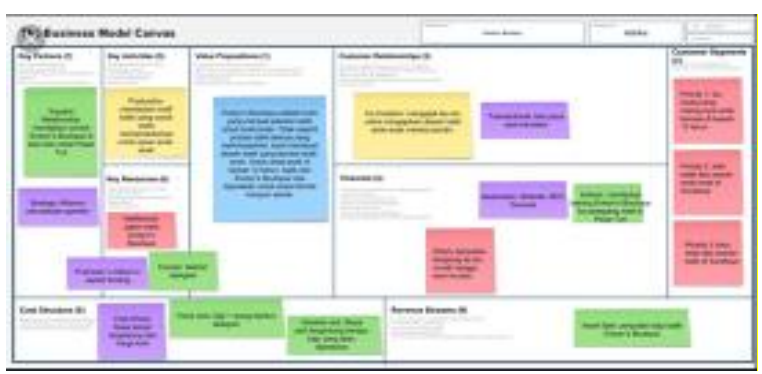

Gambar 7: Model BMC

Pelatihan manajemen permodalan bagi usaha mikro dan simulasi pembuatan proposal pengajuan kredit bank pada tanggal 17 Juli 2019. Mitra telah memiliki pengetahuan bagaimana membuat proposal pengajuan kredit ke bank dalam rangka pengembangan usaha. Mitra telah memiliki pengetahuan dan keterampilan mengenai sumber dan bagaimana memperoleh permodalan usaha. Mitra juga telah dapat mengisi formulir dan menyajikan data apa saja yang diperlukan dalam pengajuan pembiayaan ke bank. Mitra telah dapat mengisi proposal pengajuan kredit bank yang biasanya terdiri dari latar belakang perusahaan berdiri, pengalaman perusahaan dalam usahanya, target market, bahan baku dan cara mendapatkannya, omset perbulannya yang diakumulasikan pertahun, dan mencantumkan laporan keuangan. Berikut ini adalah gambar saat pelatihan manajemen permodalan usaha yang dipandu oleh Ketua Pengabdi Hendra Hadiwijaya, S.E., M.Si.

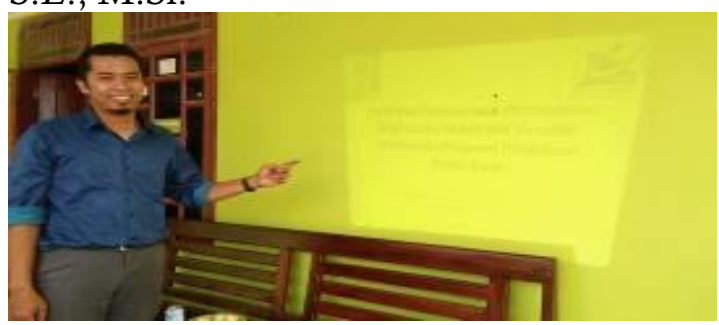

Gambar 8. Pelatihan manajemen permodalan usaha 
Berikut ini adalah modul pelatihan pengajuan kredit yang digunakan saat kegiatan pelatihan yang berisi item-item yang umumnya ada di proposal pengajuan kredit bank yang memudahkan juga untuk melakukan simulasi. Serperti pada Pengabdian yang pernah dilakukan oleh (Leiwakabessy \& Lahallo, 2018) pembiayaan dan memaksimalkan Produktifitas kegiatan UMKM dengan memanfaatkan peluang fasilitas kredit bank, dengan memaksimalkan Kredit Usaha Kecil yang merupakan solusi dalam permasalahan pembiayaan UMKM untuk lebih berkembang dan Maju

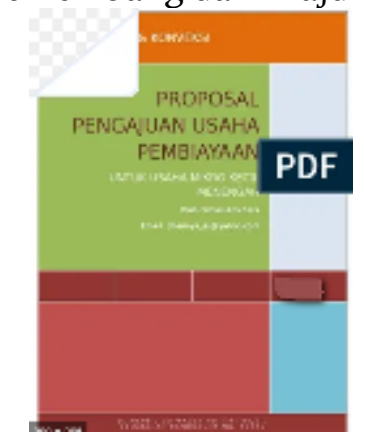

Gambar 9. Modul Proposal Pengajuan Kredit Bank

Hasil evaluasi atas kegiatan PKM ini didapatkan dari beberapa kali monev kunjungan lapangan dan pemberian kuesioner sebagai bentuk umpan balik atas kegiatan yang telah dilakukan. Pelatihan dan pendampingan perbaikan manajemen usaha dan permodalan ini telah dapat memberikan pengetahuan dan keterampilan pencatatan transaksi keuangan dan penyajian laporan keuangan usaha (secara rapi, benar, dan kontinu), serta penerapan strategi pemasaran pada usaha menggunakan BMC. Usaha Batu Bata Daslan juga mengalami kenaikan omset usaha lebih dari sebelumnya sehingga menjadi $75 \%$. Disamping itu juga terdapat peningkatan pengetahuan mengenai permodalan usaha/kredit bank pada mitra yakni: pemahaman dalam pembuatan proposal kredit bank sebesar 70\%. Pada penelitian (Hapsari, Denny Putri; Andari; Nahdiatul, 2017) penyampaian informasi dan pembimbingan personal kepada pelaku UMKM semakin meningkatkan motivasi dalam mengaplikasikan akuntansi sederhana dalam menjalankan usahanya. Hal senada yang pernah dilakukan oleh (Ayu \& Dewi, 2017) pada program kegiatan dalam peningkatan kualitas produksi dan manajemen usaha pada UMKM Genteng dan Batu Bata di Kabupaten Rembang.

\section{SIMPULAN Dan Saran}

Kegiatan PKM ini telah memberikan kemampuan keterampilan pada Usaha Batu Bata Daslan untuk melakukan pencatatan transaksi keuangan dan penyajian laporan keuangan usaha secara rapi, benar dan kontinu, peningkatan omset usaha lebih dari sebelumnya sehingga menjadi $75 \%$. Peningkatan pengetahuan mengenai permodalan usaha/kredit bank pada mitra yakni: pemahaman dalam pembuatan proposal kredit bank sebesar $70 \%$. Berdasarkan capaian hasil kegiatan PKM, maka disarankan untuk Pemilik Usaha Batu Bata Daslan tetap rutin mencatat dan menggunakan pelaporan keuangan sebagai dasar pengambilan keputusan bisnis. Disamping itu, implementasi kemampuan dalam pembuatan proposal kredit agar mendapatkan bantuan kredit bank dalam rangka meningkatkan modal guna memperluas usaha.

\section{UCAPAN TERIMA KASIH}

Penulis mengucapkan terima kasih kepada pihak yang telah memberi dukungan selama kegiatan berlangsung yaitu: Bapak Daslan yang bersedia bekerja sama sebagai mitra PKM. Direktur dan Kepala LPPM Politeknik Palcomtech dan Kepala LPPM UNSRI, serta khususnya DRPM Kementerian Riset, Teknologi, dan Pendidikan Tinggi yang telah memberikan pendanaan untuk kegiatan PKM ini.

\section{DAFTAR RUJUKAN}

Assauri, S. (2013). Manajemen Pemasaran. Rajawali Pers.

Ayu, D., \& Dewi, L. (2017). Usaha Pada Umkm Genteng Dan Batu Bata Di Kabupaten Rembang. 1(1), 34-42.

Ching, Hong, Y., \& Fauvel, C. (2013). Criticisms, variation and experiences with business model canvas. International Journal of Small Business and Entrepreneurship Research, 1(4), 18-29. 
Divianto, \& Febrianty. (2017). Pengaruh Pemahaman Pelaku UKM Dalam Menyusun Laporan Keuangan terhadap Implementasi Laporan Keuangan Berdasar SAK ETAP dengan Persepsi Pelaku UKM sebagai Moderating Variable. International Journal of Social Science and Business, 1(3), 166-176.

Ebert, R. J., \& Griffin, R. W. (2007). "Bisnis", Alih Bahasa Rd. Soemarnagara. Erlangga.

Febrianty, Divianto, Hidayat, R., Fatmariani, \& Rohana, T. (2019). The perception on technology acceptance to the behaviors on the use of social media for marketing and its implications on the turnover of creative industry MSMEs in villages. 1st International Conference on Advance and Scientific Innovation (ICASI) IOP Conf. Series: Journal of Physics: Conf. Series 1175 (2019) https://doi.org/10.1088/1742596/1175/1/012216

Hapsari, Denny Putri; Andari; Nahdiatul, A. H. (2017). Model Pembukuan Sederhana Bagi Usaha Mikro di Kecamatan Kramatwatu Kabupaten Serang. Jurnal Akuntansi, 4(2), 36-47.
Leiwakabessy, P., \& Lahallo, F. F. (2018). Pembiayaan Usaha Mikro Kecil Dan Menengah (UMKM) Sebagai Solusi Dalam Meningkatkan Produktivitas Usaha Pada Umkm Kabupaten Sorong. J-DEPACE (Journal of Dedication to Papua Community), 1(1), 11-21.

Purwanto, I. (2008). Manajemen Strategi. CV Ryama Widya.

Wibowo, D. H., Arifin, Z., \& Sunarti. (2015). Analisis Strategi Pemasaran Untuk Meningkatkan Daya Saing UMKM (Studi pada Batik Diajeng Solo). Jurnal Administrasi Bisnis (JAB), 29(1). administrasibisnis.studentjournal.ub.ac.i d.

Zubaidah, S. (2018). Pendampingan Manajemen Usaha Pada UKM IT (Information Technologi) Di Malang. Jurnal Studi Kasus Inovasi Ekonomi, 02(01), 29-34. https://doi.org/https://doi.org/10.2221 9/skie.v2i01.5496.g5252 